\title{
Perspectives
}

\section{Integrating Form and Meaning in L2 Pronunciation Instruction}

\section{Talia Isaacs}

One of the central challenges of ESL teaching is striking the right balance between form and meaning. In pronunciation pedagogy, this challenge is compounded because repetitive practice, which has been shown to enhance phonological acquisition and promote fluency, is widely viewed as being incompatible with communicative principles. This article provides a brief historical background for modern pronunciation pedagogy (from World War II to the present) as part of a backdrop for understanding the current disjuncture between pronunciation and communicative language teaching. A discussion on form-focused instruction, its applicability for pronunciation pedagogy, and challenges in implementation follows with reference to a recent article that presents evidence for the appropriateness of a communicative instructional framework for teaching L2 pronunciation (Trofimovich \& Gatbonton, 2006). Finally, a communicative activity that encourages repetitive practice while integrating pronunciation with other components of language use is proposed.

Un des principaux défis de l'enseignement de l'ALS consiste à trouver un équilibre approprié entre la forme et le sens. En pédagogie de la prononciation, ce défi est intensifié car la pratique répétitive, qui s'est avérée efficace dans l'acquisition phonologique et la promotion de la fluidité verbale, est communément perçue comme étant incompatible avec les principes communicatifs. Cet article présente un aperçu historique de la pédagogie moderne en prononciation (de la Deuxième Guerre mondiale au présent) comme fond pour comprendre l'écart actuel entre la prononciation et l'enseignement des langues par la méthode communicative. Ce survol est suivi d'une discussion sur l'instruction axée sur la forme, son applicabilité à la pédagogie de la prononciation, et les défis découlant de sa mise en pratique, le tout en faisant référence à un article récent qui présente des arguments en faveur de l'application d'un cadre reposant sur la méthode communicative pour l'enseignement de la prononciation en L2 (Trofimovich $\mathcal{E}$ Gatbonton, 2006). Finalement, nous proposons une activité communicative qui encourage la pratique répétitive tout en intégrant la prononciation à d'autres composantes liées à l'emploi de la langue. 


\section{A Historical Look at Second-Language (L2) Pronunciation Instruction}

Pronunciation enjoyed a position of prominence in the structural approach to teaching (audiolingualism), where accuracy was upheld over fluency, and pattern drills emphasized mimicry, repetition, and the eradication of deviant first language (L1) tendencies (Lightbown \& Spada, 2006; Celce-Murcia, Brinton, \& Goodwin, 1996). Typical pronunciation exercises featured decontextualized practice of minimal pairs and placed an overriding emphasis on segmentals, or individual sounds (Larsen-Freeman, 2000).

However, pronunciation experienced a fall from grace with the introduction of naturalistic approaches to teaching and the advent of communicative language teaching (CLT). From the late 1960s until the early 1980s, pronunciation was viewed as being of little importance to teaching language communicatively because it was considered part of linguistic rather than communicative competence (Pennington \& Richards, 1986). For many it symbolized the worst of the "tedious, mechanical activity" of traditional language teaching (Yule, 1990, p. 111). Moreover, it was assumed that learners' pronunciation would improve with input alone (i.e., with no pronunciation instruction). Although CLT ultimately led to a reshift in instructional emphasis from segmentals to suprasegmentals (e.g., intonation, rhythm, stress), communicative proponents failed to equip teachers adequately with strategies for teaching pronunciation communicatively (CelceMurcia et al., 1996). With few instructional materials available to interface pronunciation with communication (Grant, 1995), teachers were left to their own devices to include a pronunciation component in their teaching. This often meant choosing between teaching articulatory phonetics or no pronunciation teaching at all (Morley, 1991; Yule, 1990). Thus pronunciation was often ignored or expunged from communicative instruction (Celce-Murcia et al.). ${ }^{1}$

However, even before the advent of the communicative era, there was evidence that pronunciation was being relegated to a subordinate role compared with other skill sets. As early as 1969, Kelly argued that pronunciation was the "Cinderella of language teaching" (p. 87) in the sense that it was the component of language pedagogy that had been excluded from the royal ball (Dalton, 1997). More recently, Gilbert (1994) identified pronunciation as "an orphan in English programs around the world" (p. 38) and Celce-Murcia et al. (1996) contended that pronunciation was suffering from "the 'Cinderella syndrome' - kept behind doors and out of sight" (p. 323). This suggests that the recent history of pronunciation teaching has been far from fairytale-like: pronunciation has been marginalized from the TESL mainstream.

Since the mid-1980s, renewed interest in pronunciation has brought a concomitant push among some researchers to appropriate for pronunciation 
its rightful place in communicative language instruction (Grant, 1995; Pennington \& Richards, 1986). In a seminal article, Morley (1991) stated, "Intelligible pronunciation is an essential component of communicative competence" ( $\mathrm{p}$. 488 , emphasis in original), that "ignoring students' pronunciation needs is an abrogation of professional responsibility" (p. 489), and more recently, that pronunciation should "be written back into the instructional equation" (Morley, 1994, p. 90). In line with this, Morley explicitly drew the link between intelligibility, which has widely been recognized as an appropriate goal for pronunciation teaching (Derwing \& Munro, 1997; Field, 2005; Munro \& Derwing, 1999), and its broader effect on communication in a speech evaluation framework (Morley).

\section{Pronunciation and Communication: Still Citing Irreconcilable Differences?}

The rise in stature of pronunciation in the broader field of applied linguistics has recently been highlighted by the dedication of an entire special issue of TESOL Quarterly to pronunciation (2005). The contributions focus on a range of topics, including the nativeness and intelligibility principles-two contradictory ideologies that underlie much pronunciation research and teaching (Levis, 2005) - the role of accent as a marker of ethnic group affiliation (Gatbonton, Trofimovich, \& Magid, 2005), a research-oriented approach to developing instructional priorities (Derwing \& Munro, 2005), and the effects of misallocation of lexical stress on intelligibility (Field, 2005). TESOL Quarterly boasts the widest circulation of all peer-reviewed applied linguistics journals and features a readership of approximately 12,000 academics and practitioners (Ulrich's, 2009). Thus one might infer from the publication of this special pronunciation issue that the journal editor and presumably a growing number researchers and pedagogues (the readership) acknowledge (a) that pronunciation is often responsible for breakdowns in communication, and (b) that pronunciation should, therefore, assume a central role in communicative instruction, from which one might expect (c) that teacher training and the development of appropriate communicative pronunciation materials have followed suit. However, it seems that the field is still feeling the repercussions of the neglect of communicative proponents, first, to account adequately for the role of pronunciation in a communicative framework, and second, to propose strategies for teaching pronunciation communicatively (Celce-Murcia et al., 1996).

In a survey of 67 Canadian ESL programs, Breitkreutz, Derwing, and Rossiter (2001) found that only 30\% of teacher respondents had received pedagogical training in pronunciation. Several of the teachers identified the need to integrate pronunciation into the communicative classroom to a larger extent, but most lacked the requisite knowledge and training to do so. 
Inadequate teacher training may be a lasting effect of the deemphasis on pronunciation instruction during the communicative era due to the failure of communicative proponents to account adequately for any role for pronunciation in a communicative framework (Celce-Murcia et al., 1996). However, this is not the only reason for the existing gap between pronunciation and communicatively oriented instruction.

Currently existing instructional materials on pronunciation do not fit the bill in terms of providing authentic, context-rich activities that provide focused practice for the specific area of pronunciation to be targeted, nor do they always draw on research evidence. In a review of intonation, Levis (1999) maintained that "present intonational research is almost completely divorced from modern language teaching and is rarely reflected in teaching materials" (p. 37). He elaborated that despite a plethora of research on English intonation since the 1970s, current textbooks tended to rely heavily on archaic and often erroneous conceptions of intonation and would need to revise and update how they depicted intonation in order to get out of that time warp. Like other areas of pronunciation, intonation would benefit from increased collaboration between pronunciation researchers, pedagogues, and designers of materials (Derwing \& Munro, 2005).

Levis (1999) also noted that the treatment of intonation in textbooks was often devoid of context and lacked communicative value. He argued that although intonation had been touted as a purveyor of meaning in instructional materials, its full communicative value had not and would not be realized unless instructional activities went beyond their current focus on pattern practice and encouraged the communicative use of language.

The challenge of integrating the targeted practice of a given feature of pronunciation with meaning in instructional materials and activities is not particular to intonation, nor indeed to pronunciation. Pennington and Richards (1986) cited as artificial the separation of pronunciation from communication and from other components of language use and called for more integration. Grant (1995), in a pronunciation-based materials developer for the classroom, maintained, "of all skill areas in ESL the gap between communicative principles and classroom practice remains the most apparent in the area of pronunciation" (p. 118). To facilitate a carryover from targeted practice into spontaneous, real-word (or at least simulated) communication, Grant suggested shifting the communicative load from more to less controlled in an instructional sequence, conveying this progression by plotting activity types on a form-meaning continuum. The movement from guided (rehearsed) practice to more contextualized practice is in line with Morley's (1994) guidelines for the instructional planning of oral pronunciation activities.

Irrespective of these instructional strategies, however, it seems from the above that instructors have been less successful in bridging the gap between 
pronunciation and communication than in other areas of language instruction. This may be due to the nature of pronunciation itself, as is elaborated below after a brief excursus away from pronunciation into the broader context of classroom-centered second language (L2) research.

\section{Form-Focused Instruction and L2 Pronunciation}

Second-language acquisition (SLA) researchers have acknowledged the need to complement communicative or task-based instruction with a focus on form (Ellis, 2001; Swain, 1988). Although there are competing theories about how learners process information, most research has shown that drawing learners' attention to form-meaning relationships maximizes instruction in the communicatively oriented classroom by pushing learners to notice the gap between their un-target-like interlanguage utterances and the target form. Form-focused instruction may be deployed either reactively, in the form of corrective feedback (Lyster, 1998; Lyster \& Ranta, 1997), or preemptively in the form of preinstructional planning (Ellis, Basturkmen, \& Loewen 2001). Although the term form in focus on form or form-focused instruction has been taken to refer to a focus on grammar, vocabulary, or pronunciation in a meaning-oriented instructional context, grammar has been the focal point of most of the research. For the purposes of this article, no distinction is made between the terms focus on form and form-focused instruction.

In a discussion on the language features that most lend themselves to a focus on form, DeKeyser (1998) described as "uncontroversial" the view that "pronunciation is relatively immune to all but the most intensive formsfocused treatments" (p. 43). To support this view, he cited the point that immigrants who have not been exposed to education and formal L2 instruction often make little progress in L2 phonology or morphology and syntax. Lexical items, by contrast, can be acquired with relatively little attention to form and little conscious effort (i.e., implicitly). DeKeyser, therefore, suggests that in the case of L2 pronunciation, a focus on form may not be sufficient: phonological acquisition may require recourse to a focus on forms: that is, where the primary focus of instruction is on form rather than meaning (i.e., structure-based instruction). Although this view may have been uncontroversial at the time, recent evidence suggests that adult non-native speakers may have a short window of time early after their arrival in the host country during which they are able to improve the intelligibility of their L2 segmentals without targeted instruction (Munro \& Derwing, 2008). ${ }^{2}$ Further, Trofimovich and Baker (2006) have suggested that some suprasegmental aspects of L2 speech may actually be learned over an extended period by adult L2 learners.

To expand on DeKeyser's (1998) point, certainly the traditional instruction of pronunciation suggests that it is easily amenable to forms-focused instruction. However, to revert to an exclusive focus on forms in pronuncia- 
tion teaching would be to abandon the principles of CLT and to return to the past. Although several pronunciation proponents deplore the disjuncture between pronunciation and communication in pedagogical practice and instructional materials, few would be likely to advocate abandoning the mission and a returning to rote learning. An eclectic approach that shifts between forms-focused and form-focused instruction may be the approach to follow. However, the danger is that activities intended to focus on form may inadvertently lapse into a focus on forms. In such a scenario, instruction would lose its communicative orientation and become predominantly linguistically focused.

At the other end of the spectrum, DeKeyser's (1998) analysis suggested that an exclusive focus on meaning would not suffice for the acquisition of L2 phonological features. In fact some evidence suggests that a focus on pronunciation is better than no attention to form. In an experimental study that compared two conditions of explicit pronunciation instruction (segmentals and suprasegmentals) with a control (no specific pronunciation instruction), Derwing, Munro, and Wiebe (1998) found that the two experimental groups outperformed the control group on all measures (listeners' judgments of comprehensibility, accentedness, and fluency). This finding conforms with the general view in SLA research that a focus on form is better than no focus on form at all (Lightbown \& Spada, 2006). More research that examines the measurable effects of diverse pronunciation pedagogies on learners' gains of a target feature is necessary, as is the relationship between instruction type and short- and long-term effects of instruction.

If meaning by itself is not enough, and the desire to work in a communicative instructional methodology holds, the challenge is to provide a focus on form (in this case, pronunciation), where attention to form by definition does not detract from the overall communicative orientation of the classroom. As empirical evidence accumulates about which features of pronunciation most affect intelligibility or contribute to communication breakdowns (Hahn, 2004), then those identified features should be targeted in form-focused instruction and ordered appropriately in an instructional syllabus in conjunction with insights into teachability/learnability (Jenkins, 2000; Trofimovich, Gatbonton, \& Segalowitz, 2007).

The challenge of striking the right form-meaning balance in L2 pronunciation instruction is compounded by the fact that the acquisition of L2 phonology is facilitated by repetitive practice (Trofimovich \& Gatbonton, 2006). In strong versions of CLT, however, repetition has been viewed as incompatible with communicative principles because it has been strongly associated with (or viewed as a relic of) traditional rote learning. Gatbonton and Segalowitz (2005) argued that although communicative methodologies have stressed the importance of fluency, their avoidance of repetitive practice has meant that they fall short of promoting the requisite automatization 
that facilitates the quick retrieval of information and renders processing more efficient, one of the necessary preconditions for fluent speech. But repetition and drills need not be mechanical or incompatible with CLT. Indeed, Paulston (1970) distinguished between mechanical drills (formsfocused, reminiscent of audiolingual teaching), meaningful drills (that require the learner to process meaning but not to communicate unknown information to the listener), and communicative drills (that require the learner both to process meaning and to convey unknown content to the listener).

In a recent article that merges the pedagogic with the psycholinguistic, Gatbonton and Segalowitz (2005) proposed a theoretical teaching framework called Automatization in Communicative Contexts of Essential Speech Segments (ACCESS). The central innovation of ACCESS is that it elicits the necessary repetition to promote automatic fluency in a communicative framework that integrates attention to form (form-focused instruction). To ensure that ACCESS meets these goals appropriately, the three necessary conditions to be met for the main task are that (a) communication is genuine, with the exchange of new (unknown) information; (b) repetition is built into the task and is necessary for task completion; and (c) targeted expressions are formulaic, functional, and likely to be reencountered and reused in a future communicative situation.

Drawing on this framework, Trofimovich and Gatbonton (2006) demonstrated the applicability of ACCESS to L2 phonology. First, they provided empirical evidence from an experimental word-priming study to back the model's assumptions that learners benefit from both form-focused instruction and repetition in processing speech. Next, they explored the pedagogical implications of this finding by using the framework to model an activity that targets rising and falling intonation patterns in English. Finally, they suggested a few examples of pronunciation features that could be targeted with ACCESS for the purpose of demonstrating the generalizability of ACCESS to other areas of pronunciation. For example, the framework could be used to provide targeted communicative practice for problematic phoneme pairs that have a high functional load (Brown, 1991), because mispronunciations of high-functional-load phonemes have been shown to have a more detrimental effect on comprehensibility and accentedness than their low-functionalload counterparts (Munro \& Derwing, 2006). The usefulness of a framework like ACCESS, however, is necessarily constrained by knowledge of which features of pronunciation are most crucial for intelligibility and have the largest effect on communication.

According to Firth's (1992) zoom principle, pronunciation work should "rely on a constantly shifting focus-from overall effectiveness of communication, to a specific problem, to overall effectiveness of communication, and so on" (p. 173). That is, ESL teachers should frequently zoom in, or narrow 
the instructional focus to problematic pronunciation forms in the context of communicative activities. The following task for upper intermediate learners draws on communicative principles by incorporating realia while providing for repetitive practice and for form-meaning links to be made. Although the activity does not involve the exchange of new information (i.e., it is not genuinely communicative in Gatbonton and Segalowitz's, 2005, sense of the term), it does set the stage for other genuinely communicative activities to follow, which are elaborated below.

The activity centers on a dictation about a hair-growth product for men, here called Fast Grow, which is based on a magazine advertisement. ${ }^{3}$ Once the students have had a chance to look at the ad, the teacher reads the text below expressively, modeling, for example, the rising intonation for the yes/no questions in the first two lines.

Is your hair starting to thin?

Are you afraid of growing bald by age thirty like your uncle John?

Well, Fast Grow has the solution for you!

Our nutrient-rich regenerating cream will have your hair looking as thick as ever in just days.

With our one month money-back guarantee, you can't lose, you can only grow.

Fast Grow. Break the family tradition.

The students have the opportunity to listen to the passage multiple times during the dictation before they are required to produce the text orally, which is important in the light of evidence from the segmental literature that accurate perception precedes accurate production (Flege, 1995). Once they have written down the words, the students are instructed to circle the most prominent words in the sentence (influenced, of course, by the teacher's oral rendering). Emphasizing you in lines two and three, for example, underscores that the product is being directed to the immediate consumer and not to anyone else, an instance of implicit contrastive stress. Students can also mark down the syllable that they think has primary stress in multisyllabic words (e.g., solution) and check their accuracy when the teacher reads the passage a final time.

After going over the spelling with the class (e.g., can't vs. cannot, which is an opportunity to talk about reductions) and clarifying vocabulary, the teacher might first focus on rhythm by having the students tap out the beat and then interface rhythm with intonation by having them mimic the melodic pattern of each phrase using the nonsense syllable $d a$. Finally, after the students have practiced reciting the passage individually and as a group, they are paired with partners and asked to pretend that they are auditioning for a part in a TV commercial with their agent (their partner), whose role is to provide feedback to make their audition stronger. Incorporating techniques 
from drama such as getting students to alter their volume and play with the tenor of their voice by uttering the passage with varied emotions (e.g., quietly, hysterically) is another possibility (Celce-Murcia et al., 1996).

In the context of the communicative classroom, the above activity falls somewhere on the continuum between isolated and integrated form-focused instruction, both of which have been shown to be effective in promoting learning gains (Spada \& Lightbown, 2008). After piloting the activity on two adult ESL classes consisting of business professionals (L1 French), feedback was sought from two experienced ESL teachers who were well schooled in pronunciation pedagogy. Both teachers praised the activity for integrating pronunciation with other aspects of communication, but commented that the success of the pronunciation feedback and the quality of instruction were largely contingent on the skill of the ESL teacher.

The teacher may choose to follow up on the above activity with a genuinely communicative activity that involves pattern practice. If the target, for example, is to reinforce the intonation of yes/no questions (as in the first two lines of the Fast Grow ad.), students can play some variant of Twenty Questions, where they each have to ask directive yes/no questions to guess the identity of the person or object that their partner has chosen (e.g., Madonna, George W. Bush, a computer, etc.). In a follow-up activity, the teacher can explicitly teach the formula for writing a Fast Grow style ad. (e.g., two yes/no questions identifying a consumer need followed by a statement that the product is the solution, scientific evidence or customer testimony to make the product seem credible, and then reemphasis of the product name and a catch phrase that will make the ad. memorable). The students should then brainstorm vocabulary for a magazine ad. of their choice (e.g., face-lift cream, insect repellent, memory pills, underwater camera, pasta sauce, etc.). The teacher can monitor the students' progress in writing and in orally rehearsing their ads. Finally, the ads can be presented to the class.

\section{Conclusion}

Straddling the form-meaning continuum is one of the challenges of ESL teaching. In pronunciation pedagogy, the challenges are compounded by the importance of repetition and the widespread perceived incompatibility between repetitive practice and a communicative instructional orientation. In this article I provide a brief outline of the modern history of pronunciation pedagogy as a basis for the argument that difficulties with integrating pronunciation with communication not only are inherent to pronunciation, but also are a result of the consequences of the historical exclusion of pronunciation from the TESL mainstream. Although pronunciation is considered part of linguistic form in the literature on form-focused instruction, it has been paid little more than lip service by many SLA researchers, who have tended to focus on grammar. 
If Trofimovich and Gatbonton's (2006) article does not help curb this trend, it will at least have provided a rationale for reintegrating the use of repetition in the communicative classroom to the benefit of automatic fluency and pronunciation. Certainly validating the ACCESS model with empirical data would strengthen its claims. Future research on the ACCESS model could, for example, explore whether Gatbonton and Segalowitz's (2005) inductive approach to automatization-having repetitive practice of the target forms precede their more controlled presentation-is more effective than a deductive approach that reverses these stages (DeKeyser, 1998).

Models like ACCESS could ultimately help end the isolation of pronunciation from other areas in TESL and banish the Cinderella analogy for good by showing how pronunciation activities can be integrated with other areas of language teaching and learning. However, the accessibility of such frameworks to classroom teachers and their understanding of the purpose of the framework are crucial for success. The joint efforts of researchers and instructors would certainly facilitate the dawn of what may be a new era of communicative pronunciation pedagogy.

\section{Notes \\ ${ }^{1}$ The extent to which the shift toward suprasegmental instruction has been reflected in current ESL classroom practice is unclear. In an instructional survey in the Canadian context, for example, $89 \%$ of respondents (teachers and program coordinators) reported teaching both segmentals and suprasegmentals, $9 \%$ reported an exclusive focus on prosody, and only $2 \%$ focused solely on segmentals (Breitkreutz, Derwing, \& Rossiter, 2001). Conversely, several of the instructional materials that they reported using are exclusively segment-based. \\ ${ }^{2}$ After this initial rapid phonetic development, however, performance on segmental production tasks seems to plateau (Piske, MacKay, \& Flege, 2001). Explicit instruction might be necessary at this point to promote further improvements, particularly in segmental productions that yield low intelligibility (Munro \& Derwing, 2008). \\ ${ }^{3}$ The Fast Grow task is an original activity that I designed, which has not previously been published.}

\section{Acknowledgments}

I thank Tracey Derwing, Pavel Trofimovich, Carolyn Turner, and the anonymous TESL Canada Journal reviewers for their helpful feedback on earlier versions of this article, in addition to Sarita Kennedy and Carolyn Samuel for their substantive input on the ideas expressed here. Preparation of this manuscript was supported by funds from the Social Sciences and Humanities Research Council of Canada and Alberta Scholarship Programs.

\section{The Author}

Talia Isaacs is a doctoral student in the Faculty of Education at McGill University. She has taught ESL in various language institutes in Montreal and has instructed second-language acquisition in the university setting. Her research broadly interfaces pronunciation with L2 assessment.

\section{References}

Breitkreutz, J.A., Derwing, T.M., \& Rossiter, M.J. (2001). Pronunciation teaching practices in Canada. TESL Canada Journal, 19(1), 51-61. 
Brown, A. (1991). Functional load and the teaching of pronunciation. In A. Brown (Ed.), Teaching English pronunciation: A book of readings (pp. 211-224). London: Routledge.

Celce-Murcia, M., Brinton, D.M., \& Goodwin, J.M. (1996). Teaching pronunciation: A reference for teachers of English to speakers of other languages. Cambridge, UK: Cambridge University Press.

Dalton, D.F. (1997). Some techniques for teaching pronunciation. Internet TESL Journal, 3. Retrieved February 24, 2009, from: http://iteslj.org/Techniques/Dalton-Pronunciation.html

DeKeyser, R.M. (1998). Beyond focus on form: Cognitive perspectives on learning and practical second language grammar. In C. Doughty \& J. Williams (Eds.), Focus on form in classroom second language acquisition (pp. 42-63). Cambridge, UK: Cambridge University Press.

Derwing, T.M., \& Munro, M.J. (1997). Accent, intelligibility, and comprehensibility: Evidence from four L1s. Studies in Second Language Acquisition, 19, 1-16.

Derwing, T.M., \& M.J. Munro. (2005). Second language accent and pronunciation teaching: A research-based approach. TESOL Quarterly, 39, 379-397.

Derwing, T.M., Munro, M.J., \& Wiebe, G. (1998). Evidence in favor of a broad framework for pronunciation instruction. Language Learning, 48, 393-410.

Ellis, R. (2001). Introduction: Investigating form-focussed instruction. Language Learning, 51 (Supp. 1), 1-46.

Ellis, R., Basturkmen, H., \& Loewen, S. (2001). Preemptive focus on form in the ESL classroom. TESOL Quarterly, 35, 407-432.

Field, J. (2005). Intelligibility and the listener: The role of lexical stress. TESOL Quarterly, 39, 399-423.

Flege, J.E. (1995). Second language speech learning: Theory, findings, and problems. In W. Strange (Ed.), Speech perception and linguistic experience: Issues in cross-language research (pp. 233-277). Timonium, MD: York Press.

Firth, S. (1992). Pronunciation syllabus design: A question of focus. In P. Avery \& S. Ehrlich (Eds.), Teaching American English pronunciation (pp. 173-182). Oxford, UK: Oxford University Press.

Gatbonton, E., \& Segalowitz, N. (2005). Rethinking communicative language teaching: A focus on access to fluency. Canadian Modern Language Review, 61, 325-353.

Gatbonton, E., Trofimovich, P., \& Magid, M. (2005). Learners' ethnic group affiliation and L2 pronunciation accuracy: A sociolinguistic investigation. TESOL Quarterly, 39, 489-511.

Gilbert, J. (1994). Intonation: A navigation guide for the listener. In J. Morley (Ed.), Pronunciation pedagogy and theory: New ideas, new directions (pp. 36-48). Alexandria, VA: TESOL.

Grant, L. (1995). Creating pronunciation-based ESL materials for publication. In P. Byrd (Ed.), Material writer's guide (pp. 107-123). Boston, MA: Heinle \& Heinle.

Hahn, L. D. (2004). Primary stress and intelligibility: Research to motivate the teaching of suprasegmentals. TESOL Quarterly, 38, 201-223.

Jenkins, J. (2000). The phonology of English as an international language: New models, new norms, new goals. Oxford, UK: Oxford University Press.

Kelly, L.G. (1969). 25 centuries of language teaching: An inquiry into the science, art, and development of language teaching methodology, 500 B.C.-1969. Rowley, MA: Newbury House.

Larsen-Freeman, D. (2000). Techniques and principles in language teaching (2nd ed.). Oxford, UK: Oxford University Press.

Levis, J.M. (1999). Intonation in theory and practice, revisited. TESOL Quarterly, 33, 37-63.

Levis, J.M. (2005). Changing contexts and shifting paradigms in pronunciation teaching. TESOL Quarterly, 39, 369-377.

Lightbown, P.M., \& Spada, N. (2006). How languages are learned (3rd ed.). Oxford, UK: Oxford University Press. 
Lyster, R. (1998). Negotiation of form, recasts, and explicit correction in relation to error types and learner repair in immersion classrooms. Language Learning, 48, 183-218.

Lyster, R., \& Ranta, L. (1997). Corrective feedback and learner uptake: Negotiation of form in communicative classrooms. Studies in Second Language Acquisition, 19, 37-66.

Morley, J. (1991). The pronunciation component of teaching English to speakers of other languages. TESOL Quarterly, 25, 481-520.

Morley, J. (1994). A multidimensional curriculum design for speech-pronunciation instruction. In J. Morley (Ed.), Pronunciation theory and pedagogy: New views, new directions (pp. 64-91). Alexandria, VA: TESOL.

Munro, M.J., \& Derwing, T.M. (1999). Foreign accent, comprehensibility, and intelligibility in the speech of second language learners. Language Learning, 49 (Supp. 1), 285-310.

Munro, M.J., \& Derwing, T.M. (2006). The functional load principle in ESL pronunciation instruction: An exploratory study. System, 34, 520-531.

Munro, M.J., \& Derwing, T.M. (2008). Segmental acquisition in adult ESL learners: A longitudinal study of vowel production. Language Learning, 58, 479-502.

Paulston, C.B. (1970). Structural pattern drills: A classification. Foreign Language Annals, 4 , 187-193.

Pennington, M.C., \& Richards, J.C. (1986). Pronunciation revisited. TESOL Quarterly, 20, 207-225.

Piske, T., MacKay, I.R.A., \& Flege, J.E. (2001). Factors affecting degree of foreign accent in an L2: A review. Journal of Phonetics, 29, 191-215.

Spada, N., \& Lightbown, P.M. (2008). Form-focused instruction: Isolated or integrated? TESOL Quarterly, 42, 181-207.

Swain, M. (1988). Manipulating and complementing content teaching to maximize second language learning. TESL Canada Journal, 6(1), 68-83.

Trofimovich, P., \& Baker, W. (2006). Learning second language suprasegmentals: Effect of L2 experience on prosody and fluency characteristics of L2 speech. Studies in Second Language Acquisition, 28, 1-30.

Trofimovich, P., \& Gatbonton, E. (2006). Repetition and focus on form in processing L2 Spanish words: Implications for pronunciation instruction. Modern Language Journal, 90, 519-535.

Trofimovich, P., Gatbonton, E., \& Segalowitz, N. (2007). A dynamic look at L2 phonological learning: Seeking processing explanations for implicational phenomena. Studies in Second Language Acquisition, 29, 407-448.

Ulrich's periodicals directory. (2009). Retrieved June 21, 2009, from: http:/ / www.ulrichsweb.com/ulrichsweb/Search/fullCitation.asp?navPage=1\&tab= 1\&serial_uid=54039\&issn $=00398322$ (subscription access).

Yule, G. (1990). Review of the books Teaching English pronunciation, Teaching pronunciation: Focus on English rhythm and intonation, and current perspectives on pronunciation: Practices anchored in theory. System, 18, 107-111. 